Table 2. Association of skin psoriasis with radiographic progression in axial spondyloarthritis after 2 years of follow-up.

\begin{tabular}{|l|l|l|l|}
\hline Outcome & Psoriasis (n=28) & $\begin{array}{l}\text { No psoriasis } \\
\text { (n=185) }\end{array}$ & $\mathrm{p}^{*}$ \\
\hline \multicolumn{4}{|c|}{ Spine } \\
\hline mSASSS change & $1.52 \pm 4.02$ & $0.61 \pm 1.95$ & 0.55 \\
\hline Progression of mSASSS by 22 points & $6(21.4 \%)$ & $24(13.2 \%)$ & 0.25 \\
\hline $\begin{array}{l}\text { New syndesmophytes or progression of } \\
\text { syndesmophytes }\end{array}$ & $7(25.0 \%)$ & $26(14.3 \%)$ & 0.16 \\
\hline \multicolumn{4}{|l|}{ Sacroiliac joints } \\
\hline Change of the sacroilitits sum score & $0.18 \pm 0.63$ & $0.12 \pm 0.87$ & 0.71 \\
\hline $\begin{array}{l}\text { Progression of sacroilititis by at least 1 grade in } \\
\text { opinion of both readers }\end{array}$ & $3(10.7 \%)$ & $23(12.6 \%)$ & 1.00 \\
\hline
\end{tabular}

mSASSS - modified Stoke Ankylosing Spondylitis Spine Score.

Rudwaleit Consultant for: AbbVie, BMS, Celgene, Janssen, Eli Lilly, MSD Novartis, Pfizer, Roche, UCB Pharma, Consultant for: AbbVie, BMS, Celgene, Janssen, Eli Lilly, MSD, Novartis, Pfizer, Roche, UCB Pharma, Denis Poddubnyy Grant/research support from: AbbVie, Merck Sharp \& Dohme, Novartis, Consultant for: AbbVie, Bristol-Myers Squibb, Janssen, Merck Sharp \& Dohme, Novartis, Pfizer, UCB Pharma, Speakers bureau: AbbVie, Bristol-Myers Squibb, Janssen, Merck Sharp \& Dohme, Novartis, Pfizer, Roche, UCB Pharma

DOI: 10.1136/annrheumdis-2019-eular.7998

\section{SAT0306 COMPARISON OF MEN AND WOMEN WITH AXIAL SPONDYLOARTHRITIS IN THE US-BASED CORRONA PSORIATIC ARTHRITIS/SPONDYLOARTHRITIS (PSA SPA) REGISTRY}

Philip J. Mease ${ }^{1}$, Mei Liu², Sabrina Rebello², Robert Mclean ${ }^{2}$, Blessing Dube ${ }^{2}$ Meghan Glynn ${ }^{2}$, Esther Yi ${ }^{3,4}$, Yujin Park ${ }^{5}$, Alexis Ogdie ${ }^{6} .{ }^{1}$ Swedish Medical Center/ Providence St. Joseph Health and University of Washington, Seattle, United States of America; ${ }^{2}$ Corrona, LLC, Waltham, United States of America; ${ }^{3}$ The University of Texas at Austin, Austin, United States of America; ${ }^{4}$ Baylor Scott and White Health, Temple, United States of America; ${ }^{5}$ Novartis Pharmaceuticals Corporation, East Hanover, United States of America; ${ }^{6}$ Perelman School of Medicine at the University of Pennsylvania, Philadelphia, United States of America

Background: Axial spondyloarthritis ( $\mathrm{AxSpA})$ is a chronic inflammatory rheumatic disease that primarily affects the axial skeleton and frequently affects the peripheral joints and entheses. AxSpA encompasses ankylosing spondylitis and nonradiographic AxSpA. Sex differences have been described for patient reported outcomes (PROs) in SpA; however, more research is needed to better understand the overall clinical burden of AxSpA in women, particularly in the United States.

Objectives: To compare the patient demographics, clinical characteristics, treatment profiles, disease activity, quality of life, and work productivity between men and women with AxSpA in the US-based Corrona PsA/SpA Registry

Methods: This study included patients aged $>18$ years with $\mathrm{AxSpA}$ enrolled in the Corrona PsA/SpA Registry between March 2013 and November 2018. Patients who were concurrently diagnosed with PsA were excluded. Patient demographics, clinical characteristics, treatment profiles, disease activity, quality of life, and work productivity were characterized for all patients with AxSpA at enrollment and were compared between men and women using $t$ tests or Wilcoxon rank-sum tests for continuous variables and $\chi^{2}$ or Fisher's exact tests for categorical variables.

Results: Of 498 patients with AxSpA who were included in the study, $307(61.6 \%)$ were male and 191 (38.4\%) were female. Compared with men, women were less likely to work full time, were more likely to be normal weight/underweight, had a shorter disease duration, and were more likely to have depression, fibromyalgia, and prior CsDMARD and prednisone use (Table 1; all $P<0.05$ ). At enrollment, women with AxSpA had a shorter occiput-to-wall distance, but also had worse disease activity compared with men, as reflected by higher BASDAI and BASFI scores, higher enthesitis and tender/swollen joint counts, worse pain and fatigue, worse physical function (HAQ-S) and health state today (EQ VAS), and more severe work and activity impairment (Table 2; all $P<$ 0.05 ).

Conclusion: In this US registry of patients with AxSpA, women had an increased overall burden of disease compared with men, including higher patient reported symptoms, higher disease activity, and greater work productivity impairment. Women also had lower scores for spinal mobility with increased signs of peripheral arthritis (eg, higher tender/swollen joint and enthesitis counts), suggesting that conventional definitions of $\mathrm{AxSpA}$ centered around axial symptoms may not be representative of the female population with disease. Improved awareness of sex differences in presentation of AxSpA may aid physicians in earlier identification and improved management of the disease.

Acknowledgement: This study was sponsored by Corrona, LLC. Corrona is supported through contracted subscriptions with multiple pharmaceutical companies. The abstract was a collaborative effort between Corrona and Novartis, with financial support provided by Novartis.

Table 1. Demographic and Clinical Characteristics and Treatment Profiles in Men and

\begin{tabular}{|c|c|c|c|}
\hline \multirow[b]{2}{*}{ Characteristic } & \multicolumn{2}{|c|}{ Patients With AxSpA } & \multirow[b]{2}{*}{$P$ Value } \\
\hline & $\begin{array}{c}\text { Men } \\
(\mathrm{N}=307)\end{array}$ & $\begin{array}{c}\text { Women } \\
(\mathrm{N}=191)\end{array}$ & \\
\hline Age, mean $(\mathrm{SD})[\mathrm{n}]$, years & $47.3(13.9)[305]$ & $47.7(13.5)[190]$ & 0.75 \\
\hline Race, $n(\%)$ & $n=302$ & $n=186$ & 0.08 \\
\hline White & $276(91.4)$ & $172(92.5)$ & \\
\hline Black & $3(1.0)$ & $6(3.2)$ & \\
\hline Other & $23(7.6)$ & $8(4.3)$ & \\
\hline Work status, n (\%) & $n=306$ & $n=190$ & $<0.01$ \\
\hline Full time & $190(62.1)$ & $102(53.7)$ & \\
\hline Part time & $11(3.6)$ & $20(10.5)$ & \\
\hline Disabled & $49(16.0)$ & $24(12.6)$ & \\
\hline Retired & $38(12.4)$ & $22(11.6)$ & \\
\hline Other & $18(5.9)$ & $22(11.6)$ & \\
\hline $\mathrm{BMI}$, mean (SD) [n], kg/m² & $29.8(6.0)[297]$ & $30.0(8.5)[189]$ & 0.32 \\
\hline BMI (in $\mathrm{kg} / \mathrm{m}^{2}$ ) categories, $\mathrm{n}(\%)$ & $n=297$ & $n=189$ & 0.04 \\
\hline Normal/underweight $(<25)$ & $64(21.5)$ & $60(31.7)$ & \\
\hline Overweight $(25$ to $<30)$ & $102(34.3)$ & $54(28.6)$ & \\
\hline Obese $(\geq 30)$ & $131(44.1)$ & $75(39.7)$ & \\
\hline Symptom duration, mean (SD) [n], years & $17.6(12.3)[296]$ & $15.7(11.6)[184]$ & 0.09 \\
\hline Disease duration, mean (SD) [n], years & $10.3(10.8)[301]$ & $8.2(9.9)[188]$ & 0.02 \\
\hline HLA-B27 positive test result, $n(\%)$ & $224(73.0)$ & $124(64.9)$ & 0.06 \\
\hline \multicolumn{4}{|l|}{ Select comorbidities, $\mathrm{n}(\%)$} \\
\hline Depression & $37(12.1)$ & $49(25.7)$ & $<0.01$ \\
\hline Fibromyalgia & $3(1.0)$ & $20(10.5)$ & $<0.01$ \\
\hline Ulcerative colitis & $9(2.9)$ & $13(6.8)$ & 0.04 \\
\hline Anxiety & $7(2.3)$ & $10(5.2)$ & 0.08 \\
\hline Prior biologic use, $n(\%)$ & $89(29.0)$ & $63(33.0)$ & 0.35 \\
\hline Number of prior biologics, $n(\%)$ & & & 0.62 \\
\hline 0 & $218(71.0)$ & $128(67.0)$ & \\
\hline 1 & $57(18.6)$ & $39(20.4)$ & \\
\hline$\geq 2$ & $32(10.4)$ & $24(12.6)$ & \\
\hline Prior csDMARD use, $\mathrm{n}(\%)$ & $41(13.4)$ & $42(22.0)$ & 0.01 \\
\hline Prior prednisone use, $\mathrm{n}(\%)$ & $27(8.8)$ & $30(15.7)$ & 0.02 \\
\hline
\end{tabular}
Prior prednisone use, $n(\%)$ antirheumatic drug.

Table 2. Disease Activity, Quality of Life, and Work Productivity in Men and Women With AXSpA at Enrollment

\begin{tabular}{|c|c|c|c|}
\hline \multirow[b]{2}{*}{ Characteristic } & \multicolumn{2}{|c|}{ Patients With AxSpA } & \multirow[b]{2}{*}{$P$ Value } \\
\hline & $\begin{array}{c}\text { Men } \\
(\mathrm{N}=307)\end{array}$ & $\begin{array}{c}\text { Women } \\
(\mathrm{N}=191)\end{array}$ & \\
\hline ASDAS, mean (SD) [n] & $2.6(1.2)[179]$ & $2.8(0.9)[123]$ & 0.07 \\
\hline $\operatorname{BASDAI}(0-10)$, mean $(S D)[n]$ & $4.2(2.5)[294]$ & $4.9(2.3)[187]$ & $<0.01$ \\
\hline $\operatorname{BASFI}(0-10)$, mean $(\mathrm{SD})[\mathrm{n}]$ & $3.4(2.8)[295]$ & $4.1(2.7)[185]$ & $<0.01$ \\
\hline $\begin{array}{l}\text { Lateral lumbar flexion (average of left and } \\
\text { right), mean (SD) [n], cm }\end{array}$ & $24.1(20.1)[276]$ & $23.4(19.0)[170]$ & 0.76 \\
\hline Occiput to wall, mean (SD) [n] $\mathrm{cm}$ & $5.8(7.7)[277]$ & $2.7(5.0)[172]$ & $<0.01$ \\
\hline Enthesitis, $\mathbf{n}(\%)$ & $62(20.2)$ & $71(37.2)$ & $<0.01$ \\
\hline SPARCC Enthesitis Index (1-16) & $3.2(2.4)[62]$ & $4.8(3.2)[71]$ & $<0.01$ \\
\hline Dactylitis, n (\%) & $9(2.9)$ & $3(1.6)$ & 0.39 \\
\hline Dactylitis count (1-20) & $3.4(3.5)[9]$ & $1.3(0.6)[3]$ & 0.37 \\
\hline Tender joint count $(0-68)$, mean (SD) [n] & $1.8(4.7)[299]$ & $5.1(9.6)[190]$ & $<0.01$ \\
\hline Swollen joint count $(0-66)$, mean $(S D)[n]$ & $0.6(2.5)[299]$ & $0.9(2.2)[190]$ & 0.01 \\
\hline $\begin{array}{l}\text { Physician global assessment, } \\
\text { mean (SD) [n] }\end{array}$ & $25.7(23.4)[295]$ & $30.8(22.2)[188]$ & $<0.01$ \\
\hline Patient pain (VAS 0-100), mean (SD) [n] & $45.3(30.5)[293]$ & $51.6(27.8)[172]$ & 0.03 \\
\hline Patient fatigue (VAS $0-100$ ), mean (SD) $[n]$ & $45.4(29.1)[306]$ & $53.9(27.4)[191]$ & $<0.01$ \\
\hline Morning stiffness, $n(\%)$ & $n=299$ & $n=190$ & 0.10 \\
\hline$<30$ minutes & $88(29.4)$ & $43(22.6)$ & \\
\hline$\geq 30$ minutes & $211(70.6)$ & $147(77.4)$ & \\
\hline $\begin{array}{l}\text { Patient global assessment (VAS 0-100), } \\
\text { mean (SD) [n] }\end{array}$ & $52.2(32.5)[102]$ & $52.5(33.1)[41]$ & 0.82 \\
\hline HAQ-S (0-3), mean (SD) [n] & $0.59(0.62)[258]$ & $0.82(0.65)[131]$ & $<0.01$ \\
\hline $\operatorname{EQ~VAS~}(0-100)$, mean $(S D)[n]$ & $66.2(22.2)[298]$ & $61.1(22.4)[189]$ & $<0.01$ \\
\hline \multicolumn{4}{|l|}{ WPAI domains, mean $(\mathrm{SD})[\mathrm{n}]$} \\
\hline Current employment, $n / m(\%)$ & $206 / 304(67.8)$ & $121 / 189(64.0)$ & 0.39 \\
\hline$\%$ Work time missed & $6.7(18.4)[190]$ & $7.3(17.4)[109]$ & 0.33 \\
\hline$\%$ Impairment while working & $24.9(23.8)[199]$ & $35.4(28.5)[113]$ & $<0.01$ \\
\hline$\%$ Overall work impairment & $28.4(27.1)[184]$ & $36.4(28.6)[105]$ & 0.03 \\
\hline$\%$ Activity impairment & $36.1(29.7)[299]$ & $45.9(30.0)[188]$ & $<0.01$ \\
\hline
\end{tabular}

Ankylosing Spondylitis Disease Activity Index; BASFI, Bath Ankylosing Functional Index; EQ VAS, EuroQo visual analogue scale; HAQ-S, Health Assessment Questionnaire for the Spondyloarthropathies; SPARCC Spondyloarthritis Research Consortium of Canada; VAS, visual analog scale; WPAI, Work Productivity and 
Disclosure of Interests: Philip J Mease Grant/research support from: AbbVie, Amgen, BMS, Celgene, Janssen, Lilly, Novartis, Pfizer, SUN and UCB, Consultant for: AbbVie, Amgen, BMS, Galapagos, Gilead Sciences, Inc., Janssen, Lilly, Novartis, Pfizer, SUN and UCB, Speakers bureau: AbbVie, Amgen, BMS, Celgene, Genentech, Janssen, Lilly, Novartis, Pfizer and UCB, Mei Liu Employee of: M. Liu is an employee of Corrona, LLC., Sabrina Rebello Employee of: Corrona, LLC, Robert McLean: None declared, Blessing Dube Employee of: B. Dube is an employee of Corrona, LLC., Meghan Glynn Employee of: M. Glynn is an employee of Corrona, LLC., Esther Yi Consultant for: E. Yi is a postdoctoral fellow at the University of Texas at Austin and Baylor Scott and White Health, providing services to Novartis Pharmaceuticals Corporation., Yujin Park Employee of: Y. Park is an employee of Novartis., Alexis Ogdie Grant/ research support from: (To my university) Novartis, Pfizer, Grant/research support from: Novartis, Pfizer, Grant/research support from: Novartis, Pfizer, Grant/research support from: Novartis, Pfizer, Consultant for: AbbVie, Bristol-Myers Squibb, Celgene, Corrona, Eli Lilly and Company, Novartis, Pfizer, and Takeda, Consultant for: AbbVie, Amgen, BristolMyers Squibb, Celgene, Corrona, Eli Lilly, Novartis, Pfizer Inc, Takeda, Consultant for: Abbvie, Amgen, BMS, Celgene, Corrona, Lilly, Novartis, Pfizer, Takeda, Consultant for: Abbvie, Amgen, BMS, Celgene, Corrona, Lilly, Novartis, Pfizer, Takeda

DOI: 10.1136/annrheumdis-2019-eular.1154

\section{SAT0307 LONG-TERM ASSOCIATION BETWEEN DISEASE ACTIVITY MEASURED BY ASDAS AND PHYSICAL FUNCTION IN A LARGE EARLY AXIAL SPONDYLOARTHRITIS COHORT}

Pedro Carvalho ${ }^{1}$, Ana Marreiros ${ }^{2}$, Adeline Ruyssen-Witrand ${ }^{3}$, Pedro Machado ${ }^{4}$. ${ }^{1}$ Centro Hospitalar do Algarve - Hospital de Faro, Faro, Portugal; ${ }^{2}$ Algarve Biomedical Center, Faro, Portugal; ${ }^{3}$ Le centre Hospitalier Universitaire de Toulouse, Toulouse, France; ${ }^{4}$ University College London, London, United Kingdom

Background: The Ankylosing Spondylitis Disease Activity Score (ASDAS) has been progressively replacing the Bath Ankylosing Spondylitis Disease Activity Score (BASDAI) as the main disease activity measure to assess patients with axial spondyloarthritis (axSpA), both in the research context as well as in clinical practice. However, further evidence is needed to show its meaningfulness regarding the longitudinal relationship with physical function.

Objectives: To study the long-term association between disease activity and physical function in axSpA.

Methods: DESIR is a prospective observational cohort of patients with recent onset ( $<3$ years) inflammatory back pain, suggestive of axSpA. We analysed data collected during the first five years of follow-up and selected patients with a definite diagnosis of axSpA according to the treating rheumatologist. Physical function was assessed using the Ankylosing Spondylitis Health Assessment Questionnaire (HAQ-AS). Disease activity was measured using the ASDAS C-reactive protein (ASDAS-CRP) and BASDAI. In a first step, associations between HAQ-AS (dependent variable) and disease activity (defined by ASDAS or BASDAI), clinical and demographic variables were tested in univariable models. Multivariable models were then built adjusting for potential confounding factors found to be significant in the univariable analysis.

In a second step, additional multivariable analysis was conducted using the Chi-square Automatic Interaction Detector (CHAID) method, with HAQAS as dependent variable. The following independent variables were tested: ASDAS/BASDAI, enthesitis score, arthritis, employment status, gender, symptom duration, body mass index (BMI), HLA-B27 status, treatment with non-steroidal anti-inflammatory drugs (NSAID), conventional disease modifying anti-rheumatic drugs (CDMARD) and TNF-blockers. The final model fixed as criteria: 70 parent nodes and 20 child nodes to create new generations in the decision tree.

Results: Data from 644 patients and 4944 visits were analysed. There was a significant independent association between HAQ-AS and gender, employment status, peripheral arthritis, ASDAS-CRP/BASDAI, enthesitis, NSAID and anti-TNF treatment (Table 1). The decision tree revealed ASDAS as the first variable with discriminative power on HAQ-AS, according to the following cut points: 1.3, 2.2 and 2.4. In addition, for ASDAS values above 3.5 the model yield a higher number of explanatory variables setting different patients' profiles regarding their functional status, namely: gender, anti-TNF and NSAID treatment. Notably, the ASDAS cut-offs that separated different patient profiles largely mim icked the cut-offs previously defined for ASDAS disease activity states (inactive, low, high and very high disease activity). According to this hierarchical model, gender, anti-TNF treatment and enthesitis score were the next variables explaining $\mathrm{HAQ}-\mathrm{AS}$ variation, followed by employment status and NSAID treatment.

Conclusion: We have shown that disease activity contributes longitudinally to physical function and that it is hierarchically superior to any other variables or disease domains. Previously defined ASDAS-CRP disease activity categories identified different patient profiles on the hierarchical analysis.

\section{REFERENCE}

None.

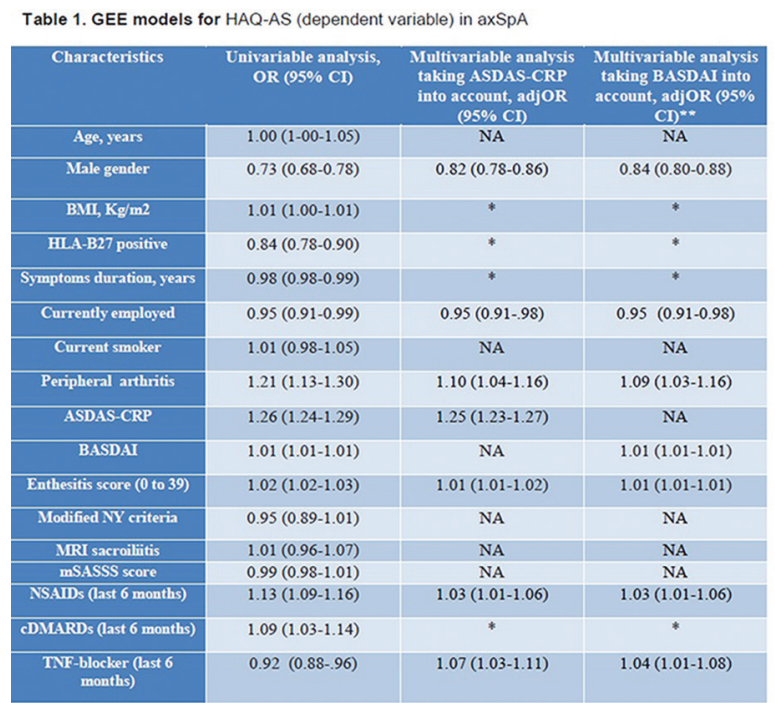

"Not selected for this model; NA - not applicable; "* Model adjusted with the cofactors considered significant in the proposed multivariable model for ASDAS (previous column)

Disclosure of Interests: Pedro Carvalho: None declared, Ana Marreiros: None declared, Adeline Ruyssen-Witrand: None declared, Pedro Machado Consultant for: Abbvie, BMS, Celgene, Janssen, MSD, Novartis, Pfizer Roche and UCB, Speakers bureau: Abbvie, BMS, Celgene, Janssen, MSD, Novartis, Pfizer, Roche and UCB

DOI: 10.1136/annrheumdis-2019-eular.1831

\section{SAT0308 CLUSTER-BASED SPONDYLOARTHRITIS PHENOTYPES DEFINED AT BASELINE ARE PREDICTIVE OF 5-YEAR SEVERITY OUTCOME IN THE DESIR COHORT}

Felicie Costantino $^{1,2}$, Philippe Aegerter ${ }^{3}$, Anna Moltó $^{4,5}$, Maxime Breban ${ }^{1,2}$, MariaAntonietta D'agostino ${ }^{1,2} .^{1}$ INSERM/Versailles-Saint Quentin University, UMR1173, Versailles-Saint Quentin, France; ${ }^{2}$ Ambroise Paré Hospital (AP-HP), Department of Rheumatology, Boulogne-Billancourt, France; ${ }^{3}$ GIRCI IdF-INSERM VersaillesSaint Quentin University, Public Health Department, Versailles-Saint Quentin, France; ${ }^{4}$ Hôpital Cochin (AP-HP), Paris Descartes University Department of Rheumatology, Paris, France; ${ }^{5}$ INSERM CRESS, U1153, Paris, France

Background: The course of axial spondyloarthritis (SpA) is heterogeneous, varying from mild to severe and remains to be better defined. DESIR is a French cohort of early undifferentiated axial SpA that are longitudinally followed-up, offering such opportunity. We recently performed a cluster analysis in the DESIR cohort, according to baseline characteristics and identified 2 clusters: one characterized by an isolated axial disorder (A for axial) and one by additional high frequency of peripheral 